\title{
Managing favors in a global economy
}

\author{
Sheila M. Puffer • Daniel J. McCarthy • \\ Mike W. Peng
}

Published online: 5 January 2013

(C) Springer Science+Business Media New York 2013

Managers engaged in the global economy continually encounter circumstances in which they wish to ask for or they themselves are approached for a favor to accomplish business objectives. Favors are also important in personal relationships, but the focus of this Special Issue is on their use in business activities, including favors that spill over from a manager's personal relationships into the business arena. Despite their importance in business, the use of favors has been an understudied phenomenon in the field of management and international business. Favors span a number of issues such as corporate growth strategies, foreign direct investment, joint ventures and other alliances, multinational headquarters-subsidiary relations, knowledge transfer, human resources management, and business ethics. Thus, this Special Issue contributes to the development of this nascent field in those arenas, although we realize that the topic has been a prominent one for decades in other fields, particularly anthropology (Malinowsky, 1922; Mauss, 1990/1950), sociology (Blau, 1964; Burt, 1992; Homans, 1958; Scott, 2008), and economics (North, 1990; Polanyi, 1957). Additionally some management authors have addressed the topic of favors either directly (Flynn, 2003), or by discussing practices that would be considered favors. Examples would be work on guanxi in China (Luo, 2007), blat/sviazi in Russia (Ledeneva, 1998, 2006), jeito in Brazil (Amado \& Brasil, 1991), and favors in India (Schuster, 2006), as well as the use of favors in all the BRIC countries (Puffer, McCarthy, Jaeger, \& Dunlap, 2013).

S. M. Puffer $(\bowtie) \cdot$ D. J. McCarthy

D'Amore-McKim School of Business, Northeastern University, Boston, MA 02115, USA

e-mail: s.puffer@neu.edu

D. J. McCarthy

e-mail: da.mccarthy@neu.edu

M. W. Peng

Jindal School of Management, University of Texas at Dallas, 800 West Campbell, SM 43, Richardson, TX 75080, USA

e-mail: apjmpeng@gmail.com 


\section{Favors are a timely topic}

The study of this topic in management and international business originated in a conference in October 2010 at Northeastern University in Boston that brought together leading scholars from various universities and management fields whose research seemed relevant to the development of a new research stream on the nature and use of favors in business. The articles in this Special Issue are a direct result of the ensuing work by those scholars and their coauthors to explore the topic through various lenses and contexts. Reflective of the timeliness and growing importance of the topic of favors, the Academy of Mangement Journal in 2011 issued a Special Research Forum call for papers, "West Meets East: New Concepts and Theories." Guanxi or other types of social relationships in the East were suggested as a topic by the guest editors as being fruitful for establishing new theories or major modifications of existing theories in management (Barkema, Chen, George, Luo, \& Tsui, 2011). The topic of favors also fits very well with the 2012 theme of the Academy of Management meetings in Boston, "The Informal Economy." As stated in the Call for Submissions, the informal economy refers to "commercial activities that occur at least partially outside a governing body's observation, taxation, and regulation." Furthermore, the informal economy is not regulated by societal institutions in the same way as is the formal economy (Bruton, Ireland, \& Ketchen, 2012). Favors obviously fall under the purview of the informal economy in the context of a formal economy, regardless of whether that formal economy is a developed one or an emerging one.

\section{The nature of favors}

Favors are important and can be helpful to doing business in a developed economy, but they exist in an environment of strong formal institutions that are generally seen as legitimate. These institutions support and legitimatize private enterprises, property rights, contract laws, consistent enforcement of laws, and countless relatively predictable and stable commercial conventions including contracts. In contrast, in spite of the diversity of countries making up emerging economies (Hoskisson, Wright, Filatotchev, \& Peng, 2013), several management scholars have identified systematic institutional and cultural differences between developed and emerging countries that have an impact on management practices and firm behavior (Aycan, 2004; Peng, 2003). Among these differences that we recognize is the culturally embedded practice of using favors that is necessary to conduct even basic business activities. In these economies, favors serve as a bridge between the formal and informal economies and are used to achieve various goals, sometimes to obtain physical goods, as well as business permits and licenses, and introductions to potential customers, suppliers, and partners. For example, transactions such as getting business permits are part of the formal economy and the use of favors to expedite them are viewed as part of the informal economy. The weakness of legitimate, formal institutions in emerging economies and similar transition economies virtually forces many people to utilize such practices (Puffer, McCarthy, \& Boisot, 2010). 


\section{Theorizing about and defining favors}

Because of their multifaceted nature, favors can be viewed from many different perspectives and can draw upon various theories. These include institutional theory, agency theory, social exchange theory, social capital theory, and stakeholder theory, as well as ethical perspectives. Various articles in this Special Issue address one or more of these theories as a lens for exploring the nature and use of favors (see Table 1).

Understandably, such diversity of theoretical foundations would bring about a diversity of definitions of what constitutes a favor in business. Yet, each article that puts forth a definition utilizes at least some elements of a relatively complete definition developed in earlier research and jointly discussed and critiqued at the Boston conference in October 2010 by all conference participants. Specifically, a favor can be defined as:

An exchange of outcomes between individuals, typically utilizing one's connections, that is based on a commonly understood cultural tradition, with reciprocity by the receiver typically not being immediate, and where the process and outcomes would not generally be considered bribery within that cultural context (McCarthy, Puffer, Dunlap, \& Jaeger, 2012: 27-28).

The elements of the definition include an exchange, connections or a network, cultural tradition, reciprocity, and the relationship with bribery.

Table 1 Papers in this Special Issue

\begin{tabular}{|c|c|c|c|c|c|c|}
\hline Authors & Theory & $\begin{array}{l}\text { Research } \\
\text { type }\end{array}$ & $\begin{array}{l}\text { Level } \\
\text { of analysis }\end{array}$ & Country/region & $\begin{array}{l}\text { Name/type } \\
\text { of favor }\end{array}$ & $\begin{array}{l}\text { Addresses } \\
\text { bribery/ } \\
\text { corruption }\end{array}$ \\
\hline Puffer et al. & Institutional & Conceptual & Macro & BRICs & $\begin{array}{l}\text { Jeito, blat/sviazi, } \\
\text { jaan pechaan, } \\
\text { guanxi }\end{array}$ & Yes \\
\hline Yakubovich & Network & Empirical & Cross-level & Russia & Job favoritism & No \\
\hline $\begin{array}{r}\text { Karam } \\
\text { et al. }\end{array}$ & $\begin{array}{l}\text { Social } \\
\text { exchange }\end{array}$ & Empirical & $\begin{array}{l}\text { Macro } \\
\text { \& micro }\end{array}$ & $\begin{array}{l}11 \text { Asian } \\
\text { countries }\end{array}$ & Favors & Yes \\
\hline $\begin{array}{l}\text { Verbeke } \\
\text { \& Kano }\end{array}$ & $\begin{array}{l}\text { Transaction } \\
\text { cost } \\
\text { economics }\end{array}$ & Conceptual & $\begin{array}{l}\text { Macro } \\
\qquad \& \text { micro }\end{array}$ & $\begin{array}{c}\text { Advanced \& } \\
\text { emerging } \\
\text { economies }\end{array}$ & Favors & Yes \\
\hline Ismail et al. & $\begin{array}{c}\text { Institutional, } \\
\text { network }\end{array}$ & Empirical & $\begin{array}{l}\text { Macro } \\
\text { \& micro }\end{array}$ & $\begin{array}{l}7 \text { countries in } \\
\text { Central Asia, } \\
\text { Caucasus }\end{array}$ & Managerial ties & No \\
\hline $\begin{array}{l}\text { Teagarden } \\
\& \text { Schotter }\end{array}$ & $\begin{array}{l}\text { Social } \\
\text { capital }\end{array}$ & Conceptual & $\begin{array}{l}\text { Macro } \\
\text { \& micro }\end{array}$ & $\begin{array}{r}\text { Emerging } \\
\text { markets }\end{array}$ & Favors & Yes \\
\hline $\begin{array}{l}\text { Thams } \\
\text { et al. }\end{array}$ & $\begin{array}{l}\text { Social } \\
\text { exchange }\end{array}$ & Conceptual & $\begin{array}{l}\text { Macro } \\
\text { \& micro }\end{array}$ & $\begin{array}{l}\text { India, Japan, } \\
\text { China }\end{array}$ & $\begin{array}{l}\text { Unnamed, } \\
\text { on, renqing }\end{array}$ & Yes \\
\hline $\begin{array}{l}\text { Mudambi } \\
\text { et al. }\end{array}$ & Institutional & Empirical & Macro & 55 countries & Corruption & Yes \\
\hline
\end{tabular}




\section{Favors and bribery}

One reason for recognizing bribery as either an extremely negative aspect of favors, or at least related to favors, is the broad understanding that the use of favors produces outcomes beyond the favor exchange process that can be viewed as positive or negative. Although our major focus is on the positive results of allowing the conduct of basic business (including reducing transaction costs) in environments where formal institutions impede rather than support such activities, favors may also lead to negative consequences such as creating an uneven playing field for various actors (especially those outside the network). Favors can also be looked upon as being hard favors that are basically self-serving rather than soft favors that benefit a larger set of actors. At the extreme, the utilization within a formal economy of informal modes of exchange, such as favors, may have negative aspects related to bribery. In fact, the topic of bribery has been researched far more deeply than the broader topic of favors (Zhou \& Peng, 2012).

\section{Favors in a global context}

This Special Issue illustrates that the construct of favors is multidimensional within cultures, and the complexity of favors manifests itself even more so across cultures, taking on different meanings and expectations in global business transactions. These differences are especially evident between developed economies with strong, legitimate supporting formal institutions and emerging economies that are generally characterized by a void of such institutions (Li, He, Lan, \& Yiu, 2012; Wu \& Chen, 2012).

Our goal is that this Special Issue will encourage further research on the use of favors in a global economy that are important for both theory and practice. Topics could include the nature of favors in various contexts, conditions under which favors are utilized, outcomes of the use of favors for business performance and personal relationships, longitudinal implications of favors and reciprocity, managing the use of favors across cultures, and the relationship with bribery including whether bribery is a manifestation of favors or distinct from that practice. These topics are vital for researchers in developing a broader theory of the use and implications of favors in management and international business. They are also critical to managers in the global economy in their role of navigating through informal channels to achieve business objectives. In both theory and practice, we believe that while it is important to recognize the potentially negative outcomes of favors, it is probably more important to appreciate the positive role that favors can play in achieving business results in a culturally and ethically acceptable way, since this positive aspect has thus far been understudied relative to the negative topic of bribery. We believe that the contributors to this Special Issue have provided the impetus for opening up numerous topics for research that should have important implications for both theory and practice

Acknowledgment This Special Issue benefitted from a conference on "Managing Favors in the Global Economy" held at Northeastern University in October 2010, where all the papers were presented and critiqued. We appreciate the funding provided by the Cherry Family Senior Fellowship, the McKimD'Amore Distinguished Professorship, and the Center for Emerging Markets, all at Northeastern, as well as the Jindal Chair at the University of Texas at Dallas. We also appreciate the comments and presentations made by authors of the papers in this Special Issue and by David Ahlstrom, Klaus Meyer, Ravi Ramamurti, W. Richard Scott, and Prakash Sethi, all of whom also made valuable contributions to the conference. 


\section{References}

Amado, G., \& Brasil, H. V. 1991. Organizational behaviors and cultural context: The Brazilian "Jeitinho". International Studies of Management \& Organization, 21(3): 38-61.

Aycan, Z. 2004. Leadership and teamwork in the developing country context. In H. W. Lane, M. L. Maznevski, M. E. Mendenhall \& J. McNett (Eds.). The Blackwell handbook of global management: A guide to managing complexity: 406-423. Malden, MA: Blackwell.

Barkema, H., Chen, X.-P., George, G., Luo, Y., \& Tsui, A. 2011. West meets East: New concepts and theories. Academy of Management Journal, 54(3): 642-644.

Blau, P. M. 1964. Exchange and power in social life. New York: Wiley.

Bruton, G. D., Ireland, R. D., \& Ketchen, D. J. 2012. Toward a research agenda on the informal economy. Academy of Management Perspectives, 26(3): 1-11.

Burt, R. 1992. Structural holes. Cambridge: Harvard University Press.

Flynn, F. J. 2003. How much should I give and how often? The effects of generosity and frequency of favor exchange on social status and productivity. Academy of Management Journal, 46(5): 539-553.

Homans, G. C. 1958. Social behavior as exchange. American Journal of Sociology, 63: 597-606.

Hoskisson, R. E., Wright, M., Filatotchev, I., \& Peng, M. W. 2012. Emerging multinationals from midrange economies: The influence of institutions and factor markets. Journal of Management Studies. doi:10.1111/j.1467-6486.2012.01085.x.

Ledeneva, A. V. 1998. Russia's economy of favours: Blat, networking and informal exchange. Cambridge: Cambridge University Press.

Ledeneva, A. V. 2006. How Russia really works: The informal practices that shaped post-Soviet politics and business. Ithaca, NY: Cornell University Press.

Li, W., He, A., Lan, H., \& Yiu, D. 2012. Political connections and corporate diversification in emerging economies: Evidence from China. Asia Pacific Journal of Management, 29(3): 799-818.

Luo, Y. 2007. Guanxi and business, 2nd ed. Singapore: World Scientific.

Malinowsky, B. 1922. Argonauts of the Western Pacific. London: Routledge \& Kegan Paul.

Mauss, M. 1990/1950. The gift: The form and reason for exchange in archaic societies. New York: W. W. Norton.

McCarthy, D. J., Puffer, S. M., Dunlap, D. R., \& Jaeger, A. M. 2012. A stakeholder approach to the ethicality of BRIC-firm managers' use of favors. Journal of Business Ethics, 109: 27-38.

North, D. C. 1990. Institutions, institutional change and economic performance. Cambridge: Cambridge University Press.

Peng, M. W. 2003. Institutional transitions and strategic choices. Academy of Management Review, 28 : 275-296.

Polanyi, K. 1957. The economy as instituted process. In K. Polanyi, C. M. Arensberg \& H. W. Pearson (Eds.). Trade and market in the early empires. New York: Free Press.

Puffer, S. M., McCarthy, D. J., \& Boisot, M. 2010. Entrepreneurship in Russia and China: The impact of formal institutional voids. Entrepreneurship: Theory and Practice, 34(3): 441-467.

Puffer, S. M., McCarthy, D. J., Jaeger, A. M., \& Dunlap, D. 2013. The use of favors by emerging market managers: Facilitator or inhibitor of international expansion?. Asia Pacific Journal of Management. doi:10.1007/s10490-012-9299-3. (This issue.)

Schuster, C. P. 2006. Negotiating in BRICs: Business as usual isn't. In S. Jain (Ed.). Emerging economies and the transformation of international business: Brazil, Russia, India and China (BRICs): 410-427. Cheltenham, UK: Edward Elgar.

Scott, W. R. 2008. Institutions and organizations: Ideas and interests. Thousand Oaks, CA: Sage.

Wu, J., \& Chen, X. 2012. Leaders' social ties, knowledge acquisition capability, and firm competitive advantage. Asia Pacific Journal of Management, 29(2): 331-350.

Zhou, J. Q., \& Peng, M. W. 2012. Does bribery help or hurt firm growth around the world?. Asia Pacific Journal of Management, 29(4): 907-921.

Sheila M. Puffer (PhD, University of California, Berkeley) is the University Distinguished Professor and Cherry Family Senior Fellow of International Business at the D'Amore-McKim School of Business, Northeastern University in Boston. Her research interests are emerging economies, with a focus on the use of favors in a global economy as well as entrepreneurship, strategy, and innovation. 
Daniel J. McCarthy (DBA, Harvard University) is the McKim-D'Amore Distinguished Professor of Global Management and Innovation at the D'Amore-McKim School of Business, Northeastern University in Boston. His research interests are emerging economies, including cultural influences, corporate governance, entrepreneurship, innovation, and strategy.

Mike W. Peng (PhD, University of Washington) is the Jindal Chair of Global Strategy at the Jindal School of Management, University of Texas at Dallas. His research interests are global strategy, international business, and emerging economies with a focus on the institution-based view. 